NATALIE R. HALBERT ${ }^{1}$, LARRY D. ROSS ${ }^{1}$, JEYARANEY KATHIRITHAMBY ${ }^{2}$, JAMES B. WOOLLEY ${ }^{1}$, REBECCA R. SAFF ${ }^{3} \&$ J. SPENCER JOHNSTON ${ }^{1}$

${ }^{I}$ Texas A\&M University

${ }^{2}$ Oxford University

${ }^{3}$ Boston University School of Medicine

\title{
PHYLOGENETIC ANALYSIS AS A MEANS OF SPECIES IDENTIFICATION WITHIN MYRMECOLACIDAE
} (STREPSIPTERA)

Halbert, N. R., L. D. Ross, J. Kathirithamby, J. B. Woolley, R. R. Saff \& J. S. Johnston, 2001. Phylogenetic analysis as a means of species identification within Myrmecolacidae (Strepsiptera). - Tijdschrift voor Entomologie 144: 179-186, fig.1, tables 1-3. [ISSN 0040-7496]. Published 1 December 2001.

The relationship between males and females of the strepsipteran Caenocholax fenyesi Pierce (Myrmecolacidae) (hosts- males: Solenopsis invicta Buren (Formicidae), females: Hapithus agitator Uhler (Orthoptera)), as well as between Stichotrema dallatorreanum Hofeneder, and other unidentified myrmecolacid females from Papua New Guinea is examined. Methods were developed for extraction, amplification, and high-resolution sequencing of mitochondrial and nuclear DNA from alcohol-preserved Strepsiptera. Phylogenetic analyses were performed in the examination of myrmecolacid family structure based upon sequences from segments of the mitochondrial Cytochrome Oxidase Subunit I (COI, 300 bases) and the nuclear 18S rRNA (18S, 213 bases) genes. Sequence analysis of the COI and $18 \mathrm{~S}$ regions showed $29 \%$ difference between the $C$. fenyesi male and putative female, $0.78 \%$ difference between two female Myrmecolacidae from West New Britain Province (WNB-A and WNB-B), and $0.95 \%$ difference between a different myrmecolacid female (WNB-C) from West New Britain Province, and a myrmecolacid female (POP) from Popondetta, Oro Province, Papua New Guinea. Comparison of levels of variation among myrmecolacid species indicates that the male $C$. fenyes $i$ and the putative female are not members of the same species. Further, two females from West New Britain Province (WNBA/B) form a new myrmecolacid species, while different females from West New Britain Province (WNB-C) and from Oro Province (POP) form a second new myrmecolacid species.

Correspondence: J. Spencer Johnston, Department of Entomology, Texas A\&M University, College Station, TX 77843 USA

Key words. - Myrmecolacidae; Caenocholax; Stichotrema; Orthoptera; Formicidae; Papua New Guinea.

Strepsiptera (Insecta), often referred to as 'stylops,' are curious entomophagous parasitoids of cosmopolitan distribution. They are curious not only for their biology but also for their host-parasitoid relationships. Kathirithamby (1989) reports that Strepsiptera are parasitic in members of seven insect orders (Thysanura, Blattodea, Mantodea, Orthoptera, Hemiptera, Hymenoptera and Diptera). The order Strepsiptera is divided into two suborders: Mengenillidia and Stylopidia (Kinzelbach 1971).

Strepsiptera have only two free-living stages: the small, active adult winged male and the $1^{\text {st }}$ instar larva. The adult males have prominent compound eyes, elegantly branched antennae, 'haltere-like' forewings, and fan-shaped hind wings. They are shortlived (some live for only two hours), they do not feed, and a breeding flight is their sole mission. With the exception of the family Mengenillidae, the bizarre adult females are neotenic. Female Mengenillidae pupate outside their host, while female Stylopidia remain permanently endoparasitic; therefore, one must look for the host to find Stylopidia females. Strepsipteran females produce viviparous $1^{\text {st }}$ instar larvae, which emerge via the brood canal opening/opening of the apron (Kathirithamby 2000) in the cephalothorax of the endoparasitic female. In endopterygote 
hosts the $1^{\text {st }}$ instars are carried back to the nests of the host (phoresy), where they enter and parasitise the eggs or larvae of the host (Kathirithamby 1989, Maeta et al. this issue). Adult male size varies between 1.6$6 \mathrm{~mm}$, while neotenic females range between $2 \mathrm{~mm}$ $2.6 \mathrm{~cm}$ (Kathirithamby 1989).

Within the suborder Stylopidia, the family Myrmecolacidae is unique. Myrmecolacid males and females not only have contrasting morphology and development, but also parasitise different hosts. Myrmecolacid males parasitise Formicidae (ants) while females parasitise Orthoptera: Tettigoniidae, Gryllidae and Gryllotalpidae (grasshoppers, crickets) and Mantodea: Mantidae (mantids). As a result of the extreme sexual dimorphism of Strepsiptera and the dual hosts of the Myrmecolacidae, it is difficult to correctly match male and female Myrmecolacidae (Kathirithamby 1989, Kathirithamby \& Hamilton 1992; Kathirithamby et al. 2001). Of the 98 species of Myrmecolacidae described, only five are of females. Of these females, only two have been identified and matched to their males. Eight species were described from males that have been found parasitic in formicid hosts, hence the hosts of only these species are known. The remaining 88 myrmecolacid species are based only on free-living males caught in light traps (Kathirithamby 1998, Kathirithamby et al. 2001). One approach used to pair males and females is to compare the respective $1^{\text {st }}$ instar larvae found in the hosts (Luna de Carvalho 1967, 1973, Cook et al. 1998). However, on host entry first instars moult to apodous second instar larvae (Kathirithamby et al. 1984) so that comparisons of this nature are generally based on the shed cuticles of the first instar rather than the entire organism. This evaluation gives tenuous and uncertain relationships since first instars have few taxonomically useful characters, and comparisons of shed cuticles are even less reliable.

\section{Caenocholax fenyesi Pierce}

Pierce (1909) originally described Caenocholax fenyesi from four males collected in Mexico by Dr. A. Fenyes. Light trap collections of $C$. fenyesi in the United States show this species is found in 7 of the southern states. C. fenyesi was first recorded stylopizing Solenopsis invicta Buren (red imported fire ant) sexuals and workers by Kathirithamby and Johnston (1992) in College Station, Texas. Stylopization of $S$. invicta by pupal stages of $C$. fenyesi causes abnormal social behaviors such as isolation, unusual posture, and decreased aggressiveness (Cook 1996). The findings of Kathirithamby and Johnston (1992) and Cook (1996) suggest potential for biological control of $S$. invicta by C. fenyesi.
Two Hapithus agitator Uhler (Orthoptera: Gryllidae, collected by Dr. R. Wharton) were found parasitised by three strepsipteran females in College Station, Texas. The females were originally identified as C. fenyesi based on external morphological comparisons of the shed $1^{\text {st }}$ instar cuticles of the male $C$. fenyesi and the $1^{\text {st }}$ instar larvae found in the putative females (Cook 1996, Cook et al. 1998).

\section{Stichotrema dallatorreanum Hofeneder}

Hofeneder (1910) described the female and $1^{\text {st }}$ instar larvae (1920) of Stichotrema dallatorreanum which parasitises Orthoptera: Tettigoniidae in Papua New Guinea (PNG). The hosts are Segestidea novaeguineae (Brancsik), Segestes decoratus Redtenbacher and Sexava nublia Stål, of which the first two are economic pests of the oil palm (Elaeis guineensis), a significant cash crop in PNG (Kathirithamby et al. 1998; Solulu et al. 1998; Kathirithamby et al. this issue). $S$. dallatorreanum is primarily, if not exclusively, parthenogenic (Kathirithamby unpublished).

\section{Unknown Species}

Two species of Tettigoniidae from PNG, Phyllophorella subinermis Karny (Phyllophorinae) from West New Britain Province (WNB-A and WNB-B) and Paracaedicia sp. (Phaneropterinae) found in West New Britain Province (WNB-C) and Popondetta, Oro Province, Papua New Guinea (POP) were found to be parasitised by unknown female Myrmecolacidae (Kathirithamby et al. this issue). The unknown species and their hosts are summarized in table 1 , along with the other species considered in this study.

\section{Locus Choice and Analysis}

Accurate and robust phylogenetic analysis requires the use of appropriately variable characters. For molecular data, this means choosing a marker that is neither hypervariable (leading to 'noisy' data) nor hypovariable (excess uninformative characters). Mitochondrial DNA sequences are commonly employed in phylogenetic studies because of their generally highly variable nature compared to nuclear loci (Vawter \& Brown 1986), which allows for the detection of genetic variation between closely related species and even individuals of the same species ( $\mathrm{Si}$ mon et al. 1994). Strepsiptera (Elenchidae) are known from the fossil record to have been present in the Late Cretaceous period 146-65mya (KukalovaPeck 1991), which necessitates the utilization of highly conserved loci. As such, Cytochrome Oxidase I (COI), which is relatively conserved among mitochondrial genes (Hillis et al. 1996), was first used as the molecular marker of choice in this study. To confirm and expand our data, we also sequenced sections of the mitochondrial $12 \mathrm{~S}$ rRNA gene, a nuclear rRNA 
Table 1. Summary of Strepsipteran species analyzed.

\begin{tabular}{|c|c|}
\hline Strepsipteran Species (family), sex & Host Species (order) \\
\hline $\begin{array}{l}\text { Stichotrema dallatorreanum Hofeneder (Myrmecolacidae), } \\
\text { female }\end{array}$ & Segestidea novaeguineae (Brancsik) (Orthoptera) \\
\hline $\begin{array}{l}\text { Elenchus japonicus }{ }^{1} \text { Esaki \& Hashimoto (Elenchidae), } \\
\text { male and female }\end{array}$ & $\begin{array}{l}\text { Sogatella furcifera Hováth, Nilaparvata lugens Stål } \\
\text { (Homoptera) }\end{array}$ \\
\hline $\begin{array}{l}\text { Caenocholax fenyesi Pierce (Myrmecolacidae), } \\
\text { putative female }\end{array}$ & Hapithus agitator Uhler (Orthoptera) \\
\hline Caenocholax fenyesi Pierce (Myrmecolacidae), male & Solenopsis invicta Bruen (Hymenoptera) \\
\hline $\begin{array}{l}\text { Species from West New Britain-A\&B (Myrmecolacidae), } \\
\text { female }\end{array}$ & Phyllophorella subinermis Karny (Orthoptera) \\
\hline Species from West New Britain-C (Myrmecolacidae), female & Paracaedicia sp. (Orthoptera) \\
\hline Species from Popondetta (Myrmecolacidae), female & Paracaedicia sp. (Orthoptera) \\
\hline Xenos vesparum Rossi ${ }^{1}$ Rossi (Stylopidae), female & Polistes dominulus Christ (Hymenoptera) \\
\hline
\end{tabular}

${ }^{1} E$. japonicus and $X$. vesparum used as outgroups for phylogenetic analysis

internal transcribed spacer, 28S D2, and the nuclear $18 \mathrm{~S}$ rRNA gene, all of which are generally presumed to be more highly variable between sequences of related taxa than COI.

The species examined in this study belong to the family Myrmecolacidae. To place the myrmecolacid sequences in a monophyletic ingroup and better determine the relationships of the species in question, Elenchus japonicus Esaki \& Hashimoto (Elenchidae) and Xenos vesparum Rossi (Stylopidae) were chosen as outgroups for sequence analysis (see table 1). Both species serve exceptionally well as outgroups because they are taxonomically outside, but closely related to, the Myrmecolacidae. E. japonicus parasitises Sogatella furcifera Horváth and Nilaparvata lugens Stål (Homoptera: Delphacidae) which are pests of rice in South Asia and South East Asia, and is a member of the family Elenchidae. The classification of Elenchidae as a sister group to Myrmecolacidae is based on morphological characters such as in the antennal joints, number of tarsal joints, and wing venation (in the male), the shape of the cephalothorax, brood canal opening (in the female), and the host group parasitised (Homoptera) (Kathirithamby 1989).

$X$ vesparum parasitises Polistes dominulus Christ (Hymenoptera: Vespidae) in the Palaearctic region and belongs to the family Stylopidae, which is the largest of the strepsipteran families.

\section{MATERIALS AND METHODS}

\section{Species Collection and DNA Extraction}

S. invicta colonies from Bee Creek Park in College Station, Texas were screened for the presence of parasitic male C. fenyesi (June \& July, 1998). The putative female $C$. fenyesi parasitic in $H$. agitator was captured in a malaise trap in Lick Creek Park, College Station, Texas, as was the unparasitised $H$. agitator. The other female Myrmecolacidae were collected during JK's field trips to PNG. JK also collected E. japonicus in Matsue, Japan, and $X$. vesparum near Florence, Italy. Samples and hosts were preserved separately in $95 \%$ ethanol.

DNA extractions were performed using a QIAamp ${ }^{\text {TM }}$ Tissue Kit (QIAGEN ${ }^{\circledR}$ ) with 25-40 mg tissue. The tissue protocol was used with the following exceptions and clarifications: samples were rinsed to eliminate excess ethanol and air dried in $1.5 \mathrm{~mL}$ microfuge tubes; Proteinase $\mathrm{K}$ digestion was performed overnight (minimum 12 hours); a 5 minute, $70^{\circ} \mathrm{C}$ incubation of the spin column loaded with $100 \mu \mathrm{L}$ $\mathrm{ddH}_{2} \mathrm{O}$ preheated to $70^{\circ} \mathrm{C}$ preceded elution; DNA was eluted twice with $100 \mu \mathrm{L} \mathrm{ddH}_{2} \mathrm{O}$ preheated to $70^{\circ} \mathrm{C}$ (total elution volume of $200 \mu \mathrm{L}$ ); extracted DNA was stored at $-20^{\circ} \mathrm{C}$. DNA was easily extracted from female Strepsiptera, but DNA extractions from males proved more difficult, possibly due to their limited size and proteinaceous exoskeleton. Female strepsipteran are larger and composed of soft tissue, which more readily permits protein degradation and nucleic acid extraction. Despite conventional precautions, the DNA from strepsipteran samples tended to degrade faster than normal when compared to host tissues and other samples in the laboratory.

\section{Locus Amplification and Sequencing}

The primer names and sequences chosen in this study are given in table 2 . Products were amplified using standard PCR techniques on a GeneAmp ${ }^{\circledR}$ PCR System 9700 (PE Applied Biosystems). All reactions were $50 \mu \mathrm{L}$ total in volume as follows: $25 \mu \mathrm{L}$ Qiagen ${ }^{\circledR}$ Taq PCR Master Mix (1.25U Taq polymerase, 
Table 2. Primer sequences.

\begin{tabular}{llll} 
Primer & Forward Sequence & Reverse Sequence & Expected Size \\
\hline 12S & 5'TACTATGTTACGACTTAT & 5'-AAACTAGGATTAGATACCC & $400 \mathrm{bp}$ \\
COI $^{1}$ & 5'GGATCACCTGATATAGCATTCCC & 5'CCCGGTAAAATTAAAATATAAACTTC & $440 \mathrm{bp}$ \\
D2 & 5'GAGTTCAAGAGTACGTGAAACCG & 5'CCTTGGTCCGTGTTTCAAGAC & $500 \mathrm{bp}$ \\
$18 \mathrm{~S}$ & 5'GCGTATACTAAAGTTGTTGCGG $^{\prime}$ & 5'GCCCTTCCGTCAATTCCTTTA & $600 \mathrm{bp}$ \\
\hline
\end{tabular}

${ }^{1}$ standardized names by Simon et al. (1994): COIF = C1-J-1751; COIR = C1-N-2191

0.5X PCR Buffer, $1.5 \mathrm{mM} \mathrm{MgCl}_{2}, 200 \mu \mathrm{M}$ each dNTP), 0.5-1 $\mu \mathrm{g}$ DNA, 10-25 pmol each primer, $1.5 \mathrm{mM} \mathrm{MgCl}_{2}$, and $\mathrm{ddH}_{2} \mathrm{O}$ to volume. Cycling conditions for COI were as follows: 1 cycle $\mathrm{X} 94^{\circ} \mathrm{C} 3 \mathrm{~min}$ utes; 40 cycles $\mathrm{X} 96^{\circ} \mathrm{C} 45 \mathrm{sec} / 46^{\circ} \mathrm{C} 45 \mathrm{sec} / 72^{\circ} \mathrm{C} 45$ sec; 1 cycle $\mathrm{X} 72^{\circ} \mathrm{C} 10 \mathrm{~min}$. Cycling conditions for $12 \mathrm{~S}$ were the same as for COI, but with a $52^{\circ} \mathrm{C}$ annealing temperature. Cycling conditions for D2 and $18 \mathrm{~S}$ were as follows: 1 cycle $\mathrm{X} 95^{\circ} \mathrm{C} 2 \mathrm{~min} ; 40$ cycles $\mathrm{X} 95^{\circ} \mathrm{C} 15 \mathrm{sec} / 52 \mathrm{C} 15 \mathrm{sec} / 68^{\circ} \mathrm{C} 5 \mathrm{sec} ; 1 \mathrm{cycle} \mathrm{X} 68^{\circ} \mathrm{C}$ 5 min. PCR products were verified on $1.2-1.5 \%$ agarose gels stained with ethidium bromide. PCR products were purified using the QIAquick ${ }^{\mathrm{TM}}$ PCR Purification Kit (QIAGEN@).

ABI Prism ${ }^{\circledR}$ BigDye ${ }^{\mathrm{TM}}$ Terminator Cycle Sequencing Ready Reaction Mix was used in the sequencing reaction. The sequencing reactions were as follows: 2 $\mu \mathrm{L}$ Big Dye ${ }^{\mathrm{TM}}, 2 \mu \mathrm{L}$ template DNA $(20 \mathrm{ng} / \mu \mathrm{L})$, and 2 $\mu \mathrm{L}$ primer $(5 \mathrm{pmol} / \mu \mathrm{L})$. The primers used for sequencing were the same as indicated for PCR. The cycling parameters followed those given for Big Dye ${ }^{T M}$ sequencing reactions. Products of the sequencing reactions were ethanol precipitated and sequenced according to standard instructions for the ABI Prism ${ }^{\circledR}$ 377 Sequencer.

\section{Data Analysis}

Sequences were obtained for at least two members of each examined species in table 1 . Forward and reverse sequences were aligned and corrected using Sequencher 3.0 (Gene Codes Corp. 1995), generating a consensus sequence for each sample. Consensus sequences were aligned with each other using CLUSTAL $\mathrm{X}$ (Higgins et al. 1992) with a gap opening of 10 , a gap extension of 0.5 , and a transition weight of 0.5 . Phylogenetic Analysis Using Parsimony (PAUP* 4.0b2, Swofford 1999) was employed for parsimony analysis of the sequences. A maximum parsimony method was used, which minimizes the number of nucleotide substitutions necessary to explain the data set. Maximum parsimony solutions were found by a branch-and-bound search followed by bootstrapping to test the strength of relationships between taxa.

\section{RESULTS}

Though sequences were obtained for all four loci for most of the taxa in question, only COI and $18 \mathrm{~S}$ proved to be reliable and conserved enough to use in this study. Sequences for the COI and $18 \mathrm{~S}$ products can be located through GenBank accession numbers AY039094-AY039107. As expected, COI was the most conserved of the 4 loci. The $12 \mathrm{~S}$ and D2 alignments contained a number of insertion/deletion events as well as single base changes. Further, the $12 \mathrm{~S}$ PCR products were consistently difficult to sequence, possibly due to the high AT content of the amplified product leading to mispriming events during sequencing. Preliminary alignments and phylogenetic analyses for the $12 S$ and D2 data were ambiguous and are consequently not included in this report.

Of the $440 \mathrm{bp}$ amplified for the COI gene region, 300 bases were sequenced and analyzed for all species named in table 1 except WNB-C. Of these, there was only a single 6 bp insertion/deletion site between $E$. japonicus/X. vesparum (families Elenchidae/Stylopidae) and all other sequences (family Myrmecolacidae). Of the approximately $600 \mathrm{bp}$ amplified for the $18 \mathrm{~S}$ gene region, 213 bases were sequenced and analyzed for all species named in table 1 except $E$. japonicus male/female and C. fenyesi male. The $18 \mathrm{~S}$ alignment contained several small gaps and more overall base differences between species than COI. When parsimony analysis was performed on either locus singly, the resulting trees were congruent with each other. That is, except for the missing taxa in each set, the data seem to have comparable phylogenetic signals. The COI+18S data set consistency was also tested using the partition homogeneity test across 1000 replicates in PAUP. The homogeneity test follows that described as the incongruence-length difference test by Farris et al. (1995). The results gave a p-value of 0.78 , indicating that the data are relatively homogeneous and that the additional homoplasy created by combining the two sets is minimal. Combining the COI and $18 \mathrm{~S}$ sequence data for this analysis also allows the inclusion of more taxa without confounding the results. Consequently, the following results were ob- 
tained by concatenating the entire 513 bp data set $(\mathrm{COI}+18 \mathrm{~S})$ in PAUP.

Table 3 shows the total number of substitutions and percent sequence divergence between taxa for COI+18S. Distances could not be determined between the following due to missing taxa between the two loci: WNB-C and $C$. fenyesi male; WNB-C and $E$. japonicus male/female. The E. japonicus male/female and $X$. vesparum taxa were treated as paraphyletic outgroups to the myrmecolacid ingroup. Parsimony analysis using the branch-and-bound method produced one most parsimonious solution of total length 433, consistency index (CI) 0.7259 , and retention index (RI) 0.7102 excluding uninformative substitutions (fig. 1). Bootstrapping support values were generated for 1000 replicates and are also shown in fig. 1 .

\section{DisCUSSION}

Comparisons of total nucleotide variation and pairwise distances (table 3) reveal that the male $C$. fenyesi and the putative female are not the same species. The male $C$. fenyesi and putative female sequences vary at 87 of the 513 bases analyzed for COI and $18 \mathrm{~S}$ (29\% corrected difference). In addition, the male $C$. fenyesi and putative female do not appear as a monophyletic clade in the phylogeny (fig. 1). In fact, the putative female $C$. fenyesi shared 31 unambiguous substitutions with the other myrmecolacids not found in the $C$. fenyesi males. In comparison, the $E$. japonicus male and female consistently showed no differences within the 300 examined bases of COI, while WNB-A/B showed two nucleotide differences (versus 87 differences in COI between C. fenyesi male/putative female). The high amount of variation between the male $C$. fenyesi and the putative female is consistent with variation between other species in this study. For instance, the nucleotide variation between $S$. dallatorreanum and WNB-A is $20 \%$, which is of the same magnitude of variation observed between the male $C$. fenyesi and putative female. The phylogenetic analysis supports the hypothesis that the female in question is of the family Myrmecolacidae, since this taxa falls between known myrmecolacid taxa (C. fenyesi male and the $\mathrm{WNB} / \mathrm{POP} / S$. dallatorreanum clade).

The high p-value for the homogeneity test $(0.78)$ and the high $\mathrm{CI}(0.7259)$ indicate that not only are the two data sets relatively homogenous, but they are also largely free of background noise. Further, the high bootstrapping values indicate the tree phylogeny is robust. As with all sequence analysis, the validity of this analysis is compromised by the possibility of contamination. In the case of parasitoid organisms, the most likely cause of contamination is the host. For this reason, DNA from hosts of E. japonicus, C. fenyesi male, $C$. fenyesi putative female, and $S$. dallatorreanum was amplified and sequenced. Comparisons of host and respective parasite partial sequences as well as GenBank BLAST searches indicated that host DNA did not contaminate the samples. Additionally, if the putative female $C$. fenyesi (or any other sample) were contaminated, presumably we would not have been able to root the 'ingroup' (theoretical composite containing a non-strepsipteran host) with a strepsipteran outgroup. At the very least, a host contaminant masquerading as a strepsipteran would be subtended on an unusually long branch. This did not occur (fig. 1). We are, therefore, confident that the sequences were not contaminated with host DNA.

As predicted by Kathirithamby (unpublished), WNB-A and WNB-B are the same species (Stichotrema jeyasothiae Kathirithamby, 2001, page 191 this issue). These taxa form a monophyletic group (fig. 1) and have a low level of sequence divergence $(0.78 \%$, table

Table 3. Base differences and total variation between taxa for COI and $18 \mathrm{~S}$ (513 bases total) are shown. ${ }^{*}$ Indicates that distances could not be calculated due to missing taxa between the two loci. Total number of substitutions is shown below the diagonal, while percent sequence divergence is shown above the diagonal.

\begin{tabular}{|c|c|c|c|c|c|c|c|c|c|c|}
\hline & 1 & 2 & 3 & 4 & 5 & 6 & 7 & 8 & 9 & 10 \\
\hline $1 S$. dallatorreanum & - & 0.19048 & 0.39464 & 0.32775 & 0.20085 & 0.20507 & 0.07619 & 0.23326 & 0.42353 & 0.42353 \\
\hline 2 POP & 88 & - & 0.33333 & 0.30580 & 0.15339 & 0.15737 & 0.00948 & O.I7444 & 0.38929 & 0.38929 \\
\hline 3 C. fenyesi male & $\mathrm{IO} 3$ & 97 & - & 0.34694 & 0.30667 & 0.31333 & $* * * * * *$ & 0.29000 & 0.39100 & 0.39100 \\
\hline $4 X$ vesparum & $\mathrm{I} 37$ & $\mathrm{I} 37$ & IO2 & - & 0.29322 & 0.29978 & O.I5337 & 0.29075 & 0.25606 & 0.25606 \\
\hline 5 WNB-A & 95 & 77 & 92 & $\mathrm{I} 34$ & - & 0.00780 & $0.0853 \mathrm{I}$ & 0.17928 & 0.37716 & 0.37716 \\
\hline $6 \mathrm{WNB}-\mathrm{B}$ & 97 & 79 & 94 & $\mathrm{I} 37$ & 4 & - & 0.09479 & 0.18725 & 0.38062 & 0.38062 \\
\hline 7 WNB-C & 16 & 2 & $*$ & 25 & I8 & 20 & - & O.I287I & $* * * * * *$ & $* * * * * *$ \\
\hline 8 C. fenyesi female & I08 & 86 & 87 & $\mathrm{I} 32$ & 90 & 94 & 26 & - & 0.37024 & 0.37024 \\
\hline 9 E. japonicus male & I08 & IO9 & $\mathrm{II} 3$ & 74 & 109 & IIO & * & 107 & - & 0.00000 \\
\hline 10 E. japonicus female & I08 & I09 & II3 & 74 & 109 & IIO & * & 107 & o & \\
\hline
\end{tabular}




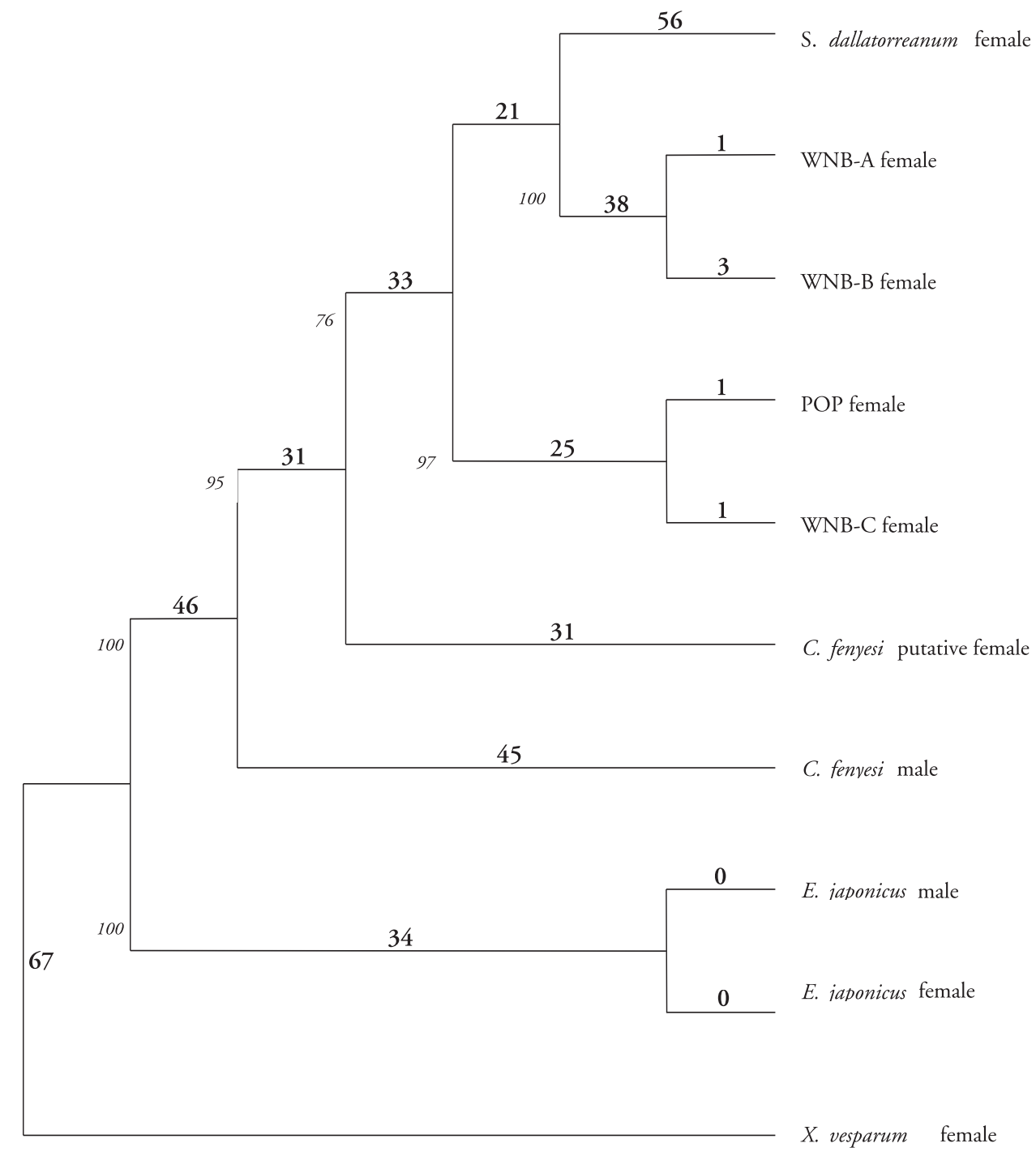

Fig. 1. Cladogram for COI \& $18 \mathrm{~S}$ sequence data rooted with $X$. vesparum and $E$. japonicus outgroups. The total tree length is 433, consistency index is 0.7259 , and retention index is 0.7102 . Numbers in bold indicate unambiguous base substitutions, while those in italics indicate bootstrap values. 
3) consistent with variation among conspecific individuals. Similarly, POP and WNB-C appear to be the same species (Stichotrema waterhousi Kathirithamby, 2001, page 195 this issue) (0.95\% difference, table 3$)$.

$S$. dallatorreanum, the clade formed by WNB-A and WNB-B females, and the clade formed by POP and WNB$C$ females form three distinct lineages supported by 56,38 , and 25 unambiguous substitutions respectively (fig. 1). These results indicate that the three groups are separate species. As such, there are currently three new species of female Myrmecolacidae: a female which parasitises H. agitator in College Station, Texas (putative $C$. fenyesi female), $S$. jeyasothieae which parasitises Phyllophorella subinermis Karny (Tettigoniidae: Phyllophorinae) in West New Britain Province and S. waterhousi which parasitises Paracaedicia sp. (Tettigoniidae: Phaneropterinae) in West New Britain Province and Popondetta, Oro Province, Papua New Guinea (Kathirithamby et al. this issue). Molecular analysis of known myrmecolacid males (without matched females), and of the few known unmatched females will likely lead to the identification of species pairs. At least in the case of the C. fenyesi in Texas, further field collections will be necessary, since there are no potential pairs for either the male $C$. fenyesi or the putative female $C$. fenyesi.

The results of this study satisfactorily prove that, even within a family as divergent as Myrmecolacidae, phylogenetic analysis of molecular data can be reliably used as a method for determining relationships between and among species given the appropriate amount of character conservation. As such, we expect that such methods will be used in the future for the identification of new species as well as the association of unmatched males and females in Strepsiptera.

\section{ACKNOWLEDGEMENTS}

We are grateful to Jerry Cook and Robert Wharton of Texas A\&M University for the collection and donation of $C$. fenyesi putative female and unparasitised $H$. agitator, to Scott Davis, Texas A\&M University, who designed the $12 S$ rRNA primers for Polistes belligreans (yellow jacket), and to Catherine Duckett, University of Puerto Rico, who recommended the D2 and $18 \mathrm{~S}$ primers based on previous experience, to the Entomology Division, Papua New Guinea Oil Palm Association Inc., Professor Y. Maeta's lab (Faculty of Life and Enviromental Science, Shimane University, Matsue, Japan), and Professor S. Turallizzi's lab (Department of Animal Biology and Genetics 'Leo Pardi', University of Florence, Italy) for helping JK in collection of the specimens. Field collections carried out by JK were on grants from the Papua New Guinea Oil Palm Association Inc. (to PNG), the British Council
Travel grant (to Japan), and the Royal Society Travel Grant (to Italy).

\section{REFERENCES}

Cook, J. L, 1996. A study of the relationship between Caenocholax fenyesi Pierce (Strepsiptera, Myrmecolacidae) and the red imported fire ant, Solenopsis invicta Buren (Hymenoptera, Formicidae). - Ph.D. dissertation, Texas A\&M University, College Station.

Cook, J. L., S. B. Vinson, \& R. Gold, 1998. Developmental Stages of Caenocholax fenyesi Pierce (Strepsiptera: Myrmecolacidae): Descriptions and significance to the higher taxonomy of Strepsiptera. - International Journal of Insect Morphology \& Embryology 27: 21-26.

Farris, J. S., M. Kallersjo, A. G. Kluge, \& C. Bult, 1995. Testing significance of incongruence. - Cladistics 10: 315-319.

Higgins, D. G., A. J. Bleasby, \& R. Fuchs, 1992. CLUSTAL V: Improved software for multiple sequence alignment. - Cabios 8: 189-191.

Hillis, D. M., C. Moritz, \& B. K. Mable [eds.], 1996. Molecular Systematics, $2^{\text {nd }}$ ed. Sinauer, Sunderland, Massachusetts.

Hofeneder, K, 1910. Stichotrema n. g. dallatorreanum n. sp. eine in einer Orthoptere lebende Strepsiptere. - Zoologischer Anzeiger 36: 47-49.

Hofeneder, K., 1920. Stichotrema Dalla-Torreanum mihi. Eine neue Strepsiptere aus einer Orthoptere. - Abhandlungen von der Senckenbergischen Naturforschenden Gesellschaft.36(4): 439-446

Kathirithamby, J, 1989. Review of the Order of Strepsiptera. - Systematic Entomology 14: 41-92.

Kathirithamby, J, 1998. Host-parasite associations: anatomi$\mathrm{cal}$ and developmental consequences. - International Journal of Insect Morphology \& Embryology 27(1): 39-51.

Kathirithamby, J., 2000. Morphology of the female Myrmecolacidae (Strepsiptera) including the apron, and an associated structure analogous to the peritrophic matrix. - Biological Journal of the Linnean Society 128: 269-287.

Kathirithamby, J., D. S. Smith, M. B. Lomas, \& B. M. Luke, 1984. Apolysis without ecdysis in larval development of a strepsipteran, Elenchus tenuicornis (Kirby). Zoological Journal of the Linnean Society 82: 335-343.

Kathirithamby, J. \& W. D. Hamilton, 1992. More covert sex: the elusive females of Myrmecolacidae. - Trends in Ecology and Evolution 7(10): 349-351.

Kathirithamby, J. \& J. S. Johnston, 1992. Stylopization of Solenopsis invicta (Hymenoptera: Formicidae) by Caenocholax fenyesi (Strepsiptera: Myrmecolacidae) in Texas. Annals of the Entomological Society of America 85(3): 293-297.

Kathirithamby, J., S. Simpson, T. Solulu, \& R. Caudwell.1998. Strepsiptera parasites novel biocontrol tools for oil palm integrated pest management in Papua New Guinea. - International Journal of Pest Management 44: 127-133.

Kathirithamby, J., T. Solulu \& R. Caldwell, 2001. Description of female Myrmecolacidae (Strepsiptera) parasitic in Orthoptera (Tettigoniidae) in Papua New Guinea. - Tijdschrift voor Entomologie 144: 187-196.

Kinzelbach. R. K., 1971. Morphologische Befunde an Fächerflüglern und ihre phylogenetische Bedeutung (Insecta:Strepsiptera). - Zoologica 119: 256 pp. 
Kukalova-Peck, J, 1991. Fossil History and the Evolution of Hexapod Structures, pp. 141-179. - In: I. D. Naumann [ed.], The Insects of Australia. $2^{\text {nd }}$ edition. Cornell Univ. Press, New York.

Luna de Carvalho, E., 1967. Terceira contribuição para o estudo dos Estrepsípteros angolenses (Insecta, Strepsiptera). - Publicações Culturais da Companhia de Diamantes de Angola 77: 13-66.

Luna de Carvalho, E., 1973. Estudo sobre o 'Mantidoxenos argentinus' (Myrmecolax ogloblini), nom. nov. (Insecta Strepsiptera Myemcolacidae). - Ciência Biologica 1: 51056.

Pierce, W. D., 1909. A monographic revision of the twisted winged insects comprising the order Strepsiptera Kirby. Bulletin of the United States National Museum 66: 1232.

Simon, C., F. Frati, A. Beckenbach, B. Crespi, H. Liu, \& P. Flook, 1994. Evolution, weighting, and phylogenetic utility of mitochondrial gene sequences and a compilation of conserved polymerase chain reaction primers. - Annals of the Entomological Society of America 87: 651-701.
Solulu, T. M, 1997. Influence of Stichotrema dallatorreanum Hofender (Strepsiptera: Myrmecolacidae) on the performance of Segestidea novaeguinea (Bransisk) (Orthoptera: Tettigoniidae) in Papua New Guinea. - M.S. thesis. Oxford University, Oxford.

Solulu, T. M., S. J. Simpson, \& J. Kathirithamby, 1998. The effect of strepsipteran parasitism on a tettigoniid pest of oil palm in Papua New Guinea. Physiological Entomology 23: 388-398.

Swofford, D. L, 1999. PAUP*. - Phylogenetic Analysis Using Parsimony (*and other methods). Version 4. Sinauer Associates, Sunderland, Massachusetts.

Vawter, L. \& W. M. Brown, 1986. Nuclear and mitochondrial DNA comparisons reveal extreme rate variation in the molecular clock. - Science 234:194-196.

Received: 8 June 2001

Accepted: 23 July 2001 